\title{
Synaptic Plasticity in Hippocampal CA1 Neurons of Mice Lacking Type 1 Inositol-1,4,5-Trisphosphate Receptors
}

\author{
Satoshi Fujii, ${ }^{1,4}$ Mineo Matsumoto, ${ }^{2}$ Kotaro Igarashi, ${ }^{1}$ Hiroshi Kato, ${ }^{1}$ and \\ Katsuhiko Mikoshiba ${ }^{2,3}$ \\ ${ }^{1}$ Department of Physiology, Yamagata University School of Medicine, Yamagata 990-9585, Japan; ${ }^{2}$ Department of Molecular Neurobiology, \\ Institute of Medical Science, University of Tokyo, Tokyo 108-8639, Japan; ${ }^{3}$ Exploratory Research for Advanced Technology, Japan Science and \\ Technology Cooperation, Tokyo 113-0012, Japan
}

\begin{abstract}
In hippocampal CA1 neurons of wild-type mice, delivery of a standard tetanus (100 pulses at $100 \mathrm{~Hz})$ or a train of low-frequency stimuli (LFS; 1000 pulses at $1 \mathrm{~Hz}$ ) to a naive input pathway induces, respectively, long-term potentiation (LTP) or long-term depression (LTD) of responses, and delivery of LFS 60 min after tetanus results in reversal of LTP (depotentiation, DP), while LFS applied 60 min before tetanus suppresses LTP induction (LTP suppression). To evaluate the role of the type 1 inositol-1,4,5-trisphosphate receptor (IP3R1) in hippocampal synaptic plasticity, we studied LTP, LTD, DP, and LTP suppression of the field excitatory postsynaptic potentials (EPSPs) in the CA1 neurons of mice lacking the IP3R1. No differences were seen between mutant and wild-type mice in terms of the mean magnitude of the LTP or LTD induced by a standard tetanus or LFS. However, the mean magnitude of the LTP induced by a short tetanus (10 pulses at $100 \mathrm{~Hz}$ ) was significantly greater in mutant mice than in wild-type mice. In addition, DP or LTP suppression was attenuated in the mutant mice, the mean magnitude of the responses after delivery of LFS or tetanus being significantly greater than in wild-type mice. These results suggest that, in hippocampal CA1 neurons, the IP3R1 is involved in LTP, DP, and LTP suppression but is not essential for LTD. The facilitation of LTP induction and attenuation of DP and LTP suppression seen in mice lacking the IP3R1 indicates that this receptor plays an important role in blocking synaptic potentiation in hippocampal CA1 neurons.
\end{abstract}

Several types of activity-dependent synaptic plasticity are seen in hippocampal CA1 neurons. One of these, known as long-term potentiation (LTP), that is, persistent synaptic enhancement induced by a brief period of high-frequency electrical stimulation (HFS) of afferents (Bliss and GardnerMedwin 1973; Bliss and Lømo 1973), is well-known and is assumed to be responsible for important processes involved in the cellular basis of memory and learning (Bliss and Collingridge 1993). Another, known as long-term depression (LTD), involves the depression by low-frequency afferent stimulation (LFS) of a response in a naive pathway (Dudeck and Bear 1992). Two further types of synaptic plasticity have been reported in these neurons; these are known as depotentiation (DP), in which LFS reverses a pre-established LTP (Fujii et al. 1991; Bashir and Collingridge 1994), and LTP suppression, in which a train of LFS given before the delivery of HFS suppresses LTP induction (Fujii et al. 1996, 2000).

${ }^{4}$ Corresponding author.

E-MAIL sfujii@med.id.yamagata-u.ac.jp; FAX 81236285221. Article and publication are at www.learnmem.org/cgi/doi/ $10.1101 / \mathrm{lm} .34100$.
Previous studies of hippocampal CA1 neurons have shown that activation of both N-methyl-D aspartate (NMDA) receptor/ $\mathrm{Ca}^{2+}$ channels and metabotropic glutamate receptors (mGluRs) is a necessary step for the induction of homosynaptic LTP (Bashir et al. 1993; Bliss and Collingridge 1993). In addition, DP in CA1 neurons has been reported to be blocked by NMDA antagonists (Fujii et al. 1991; O'Dell and Kandel 1994) or an mGluR antagonist (Bashir and Collingridge 1994). Furthermore, Bortolotto et al. (1994) have shown the role of mGluRs in LTP induction to be a molecular switch mechanism, LTP induction being suppressed when the mGluR-activated switch is turned off by LFS. Thus, in hippocampal CA1 neurons, mGluR activation is also involved in the mechanism of LTP suppression, which is dependent on activation of NMDA receptor/ $/ \mathrm{Ca}^{2+}$ channels during LFS (Fujii et al. 1996).

However, although the homosynaptic LTD induced by LFS appears to require activation of NMDA receptor/Ca ${ }^{2+}$ channels (Dudeck and Bear 1992; Mulkey and Malenka 1992; Linden 1994), the involvement of mGluRs in LTD in hippocampal CA1 neurons is still controversial. Oliet et al. (1997) showed the co-existence of two mechanistically distinct forms of LTD in hippocampal CA1 neurons in juvenile

LEARNING \& MEMORY 7:312-320 @ 2000 by Cold Spring Harbor Laboratory Press ISSN1072-0502/00 \$5.00

$$
\begin{array}{lllllllllllllll}
L & E & A & R & N & I & N & G \quad & \mathbb{Z} & M & E & M & O & R & Y \\
\text { www.learnmem.org } & \\
312 &
\end{array}
$$


rats, one of which is dependent on the activation of T-type voltage-gated $\mathrm{Ca}^{2+}$ channels (VGCCs), group I mGluRs, and protein kinase $\mathrm{C}(\mathrm{PKC})$ and the other on the activation of NMDA receptors. Other studies have shown that the homosynaptic LTD induced in CA1 neurons by the activation of mGluRs may not require activation of NMDA receptors (Palmer et al. 1997; Otani and Connor 1998).

Stimulation of group I mGluRs in hippocampal CA1 neurons activates phospholipase C (PLC), which hydrolyses the inositol lipid precursor in the postsynaptic plasma membrane into inositol 1,4,5-trisphosphate (IP3) and diacylglycerol (DAG), the former of which opens IP3 receptor channels, while the latter activates PKC (Ben-Ari et al. 1992; Nakanishi 1992). In hippocampal CA1 neurons, DAG or PKC has been proposed to be involved in the induction of LTP (Kato et al. 1991; Abeliovich et al. 1993).

The IP3 receptor (IP3R) acts as an IP3-gated $\mathrm{Ca}^{2+}$ release channel in a variety of cells (Berridge 1993; Mikoshiba 1993). The type 1 IP3R (IP3R1) is the major neuronal member of the IP3R family in the central nervous system and is predominantly enriched in cerebellar Purkinje cells and hippocampal CA1 neurons (Furuichi et al. 1993). Recently, Inoue et al. (1998) demonstrated that LTD is disrupted in the cerebellar Purkinje cells of mice lacking the IP3R1. In this study, we employed IP3R1 knockout mice, produced by a gene-targeting method (Matsumoto et al. 1996), to investigate the role of the IP3R1 in the induction of LTP, LTD, DP, and LTP suppression in hippocampal CA1 synapses.

\section{RESULTS}

\section{LTP in Hippocampal CA1 Neurons of Mice Lacking the IP3R1}

At hippocampal CA1 neuron synapses, a short tetanus (10 pulses at $100 \mathrm{~Hz}$ ) induced a robust LTP in mutant mice but failed to do so in wild-type mice. Figure 1A shows sample waveforms and an example of the time-course of LTP in a representative slice from a mutant and a wild-type mouse. In the case of the mutant mouse, the short tetanus evoked a marked increase in the S-EPSP that was maintained for $>1$ $\mathrm{h}$, whereas, in the wild-type mouse, it evoked short-term potentiation (STP), which then gradually fell back almost to pretetanic levels within 40-50 min.

The summarized results from five experiments in four mutant mice and seven in five wild-type mice (Fig. 1B) clearly show that a robust LTP was induced in slices from mutant mice but not in slices from wild-type mice. Sixty minutes after the tetanus, the S-EPSP in slices from mutant and wild-type mice were, respectively, $137.6 \% \pm 8.7 \%$ and $103.9 \% \pm 5.3 \%$ of the original control levels. As the former value is significantly larger than the latter $(P<0.01)$, we conclude that LTP induction is facilitated at CA1 synapses in mice lacking the IP3R1.
In mutant mice, the LTP induced by delivery of a short tetanus was dependent on activation of NMDA glutamate receptors $/ \mathrm{Ca}^{2+}$ channels, as LTP induction in the S-EPSP was blocked in the presence of the NMDA receptor antagonist, AP5 $(10 \mu \mathrm{M})$. Sample waveforms and an example of the time-course of LTP in a representative slice in the presence of AP5 are shown in Figure 1C. The summarized results from six experiments in six mutant mice (Fig. 1D) show failure of LTP induction by a short tetanus applied in the presence of AP5, the S-EPSP measured $60 \mathrm{~min}$ after the short tetanus being $103.2 \% \pm 4.1 \%$ of the control level, significantly $(P<0.01)$ lower than the control LTP level induced in the mutant mice.

In contrast, a standard tetanus (100 pulses at $100 \mathrm{~Hz})$ induced a robust LTP in slices from both mutant and wildtype mice. Figure 2 shows a representative time-course (Fig. 2A) and the summarized results (Fig. 2B) for slices from mutant or wild-type mice. To statistically evaluate LTPs, we measured the S-EPSP 20, 60, and 140 min after tetanus in five slices from five mutant or five wild-type mice. In the mutant mice, these values were, respectively, $180.9 \% \pm$ $13.1 \%, 156.0 \% \pm 10.2 \%$, and $159.7 \% \pm 8.5 \%$ of the pretetanic control level, whereas, in wild-type mice, the corresponding values were $162.3 \% \pm 6.1 \%, 162.8 \% \pm 6.8 \%$, and $163.4 \% \pm 8.0 \%$, with no significant difference between the groups. Thus, the standard tetanus induced a similar degree of LTP in both genotypes, and LTP was maintained for at least $140 \mathrm{~min}$.

\section{Depotentiation of LTP in Hippocampal CA1 Neurons of Mice Lacking the IP3R1}

In the hippocampal CA1 neurons of wild-type mice, LFS reverses the homosynaptic LTP in the S-EPSP (depotentiation of LTP; DP; Fujii et al. 1991). However, in slices from mutant mice, a standard LFS (1000 pulses at $1 \mathrm{~Hz})$, applied $60 \mathrm{~min}$ after a standard tetanus $(100$ pulses at $100 \mathrm{~Hz})$, had a significantly smaller effect on an established LTP. Figure $3 \mathrm{~A}$ shows a representative DP time-course in slices from a mutant and a wild-type mouse. The summarized data (Fig. 3B) show that the DP in the S-EPSP in six slices from three mutant mice was markedly attenuated compared with that in seven slices from four wild-type mice. The LTP values 60 min after tetanus were almost identical in the two groups of mice, being $155.8 \% \pm 11.4 \%$ and $150.4 \% \pm 5.0 \%$ of the pretetanic control level in the mutant and wild-type mice, respectively.

LFS delivered 60 min after tetanus significantly reduced an established LTP (DP) in wild-type mice but had no effect in mutant mice. In mutant mice, the S-EPSP measured 60 min after the end of LFS was $151.5 \% \pm 10.3 \%$ of the pretetanic control level $(n=6)$, no different from the control LTP measured 140 min after tetanus (Fig. 2B), whereas in wildtype mice, DP was induced by LFS, the S-EPSP measured 60

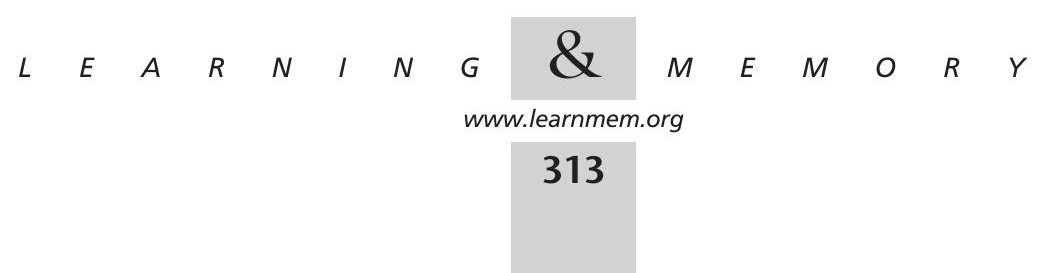



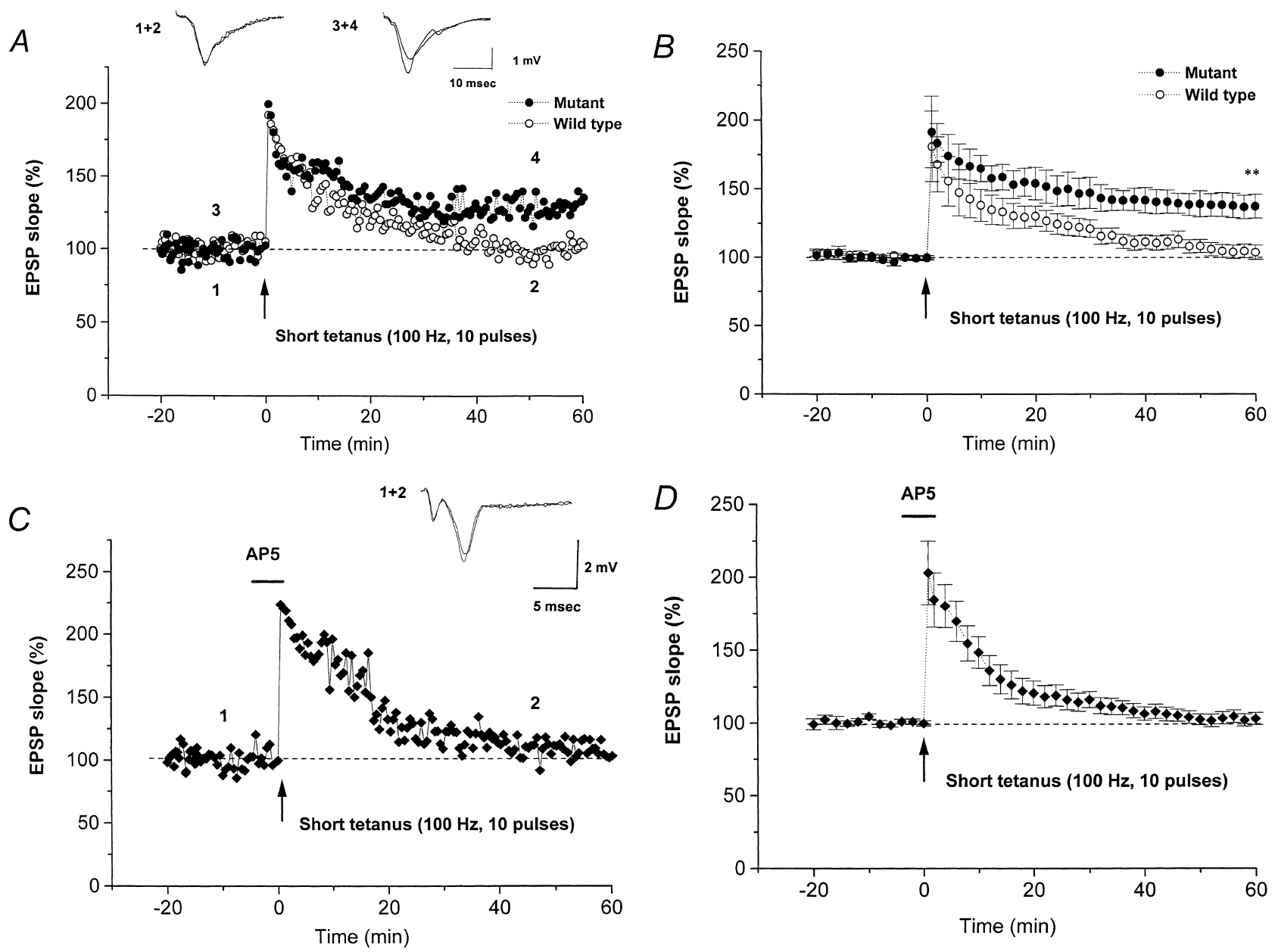

Figure 1 LTP induced by a short tetanus at hippocampal CA1 synapses of wild-type and mutant mice lacking the IP3R1. (A) Typical examples of waveforms and the time-course of S-EPSP. A short tetanus $(10$ pulses, $100 \mathrm{~Hz})$ induced LTP in a slice from a mutant mouse (closed circles), but failed to do so in a slice from a wild-type mouse (open circles). (B) Summarized results for the time-course of LTP in the S-EPSP in wild-type mice ( $n=6$, open circles) or mutant mice ( $n=6$, closed circles). (C) Typical example showing that the effect of a short tetanus in a mutant mouse was blocked by AP5 $(10 \mu \mathrm{M}$, horizontal bar; closed diamonds). The insert shows sample traces of the field EPSP at the times indicated. (D) Summarized results for the time-course of LTP in the S-EPSP in mutant mice in the presence of AP5 $(n=6)$. In this and the following figures, the plots show the mean \pm SEM. ${ }^{* *}$, significant $(P<0.01)$ difference at 60 min after tetanus between the slices from wild-type and mutant mice.

min after the end of LFS being only $116.2 \% \pm 5.9 \%$ of the pretetanic control level $(n=7)$, significantly $(P<0.01)$ lower than the control LTP measured $140 \mathrm{~min}$ after a standard tetanus (Fig. 2B). Statistical analysis of the LTP measured $60 \mathrm{~min}$ after LFS indicates a significant $(P<0.05)$ difference between the mutant and wild-type mice. From these results, we conclude that DP is blocked at CA1 synapses of mice lacking the IP3R1.

The DP induced in wild-type mice was dependent on activation of NMDA glutamate receptors $/ \mathrm{Ca}^{2+}$ channels, as a standard LFS given in the presence of $50 \mu \mathrm{M}$ AP5 failed to induce DP in CA1 neurons of slices from wild-type mice. An S-EPSP time-course plot from a representative slice from a wild-type mouse is shown in Figure 3C, and the summarized results from four slices in three wild-type mice are shown in
Figure 3D. In these slices, the LTP $60 \mathrm{~min}$ after tetanus was $156.2 \% \pm 7.1 \%$ of the pretetanic control level, while the S-EPSP measured $60 \mathrm{~min}$ after the end of LFS was $157.2 \% \pm 8.1 \%$ of the pretetanic control level $(n=6)$, no different from the control LTP measured 60 and 140 min after tetanus (Fig. 2B). Statistical analysis of the LTP measured $60 \mathrm{~min}$ after the standard LFS indicates a significant $(P<0.01)$ difference between DPs induced in the absence and presence of AP5. These results show that DP induced in hippocampal CA1 neurons requires the activation of NMDA receptor/ $\mathrm{Ca}^{2+}$ channels during delivery of the standard LFS. Thus, we conclude that, in these cells, IP3R1 is involved in the mechanism of DP, which requires the activation of NMDA receptor/ $\mathrm{Ca}^{2+}$ channels during LFS.

$$
\begin{array}{lllllllllllllll} 
& E & A & R & N & I & N & G & \mathcal{Q} & M & E & M & O & R & Y \\
\text { www.learnmem.org } & & &
\end{array}
$$



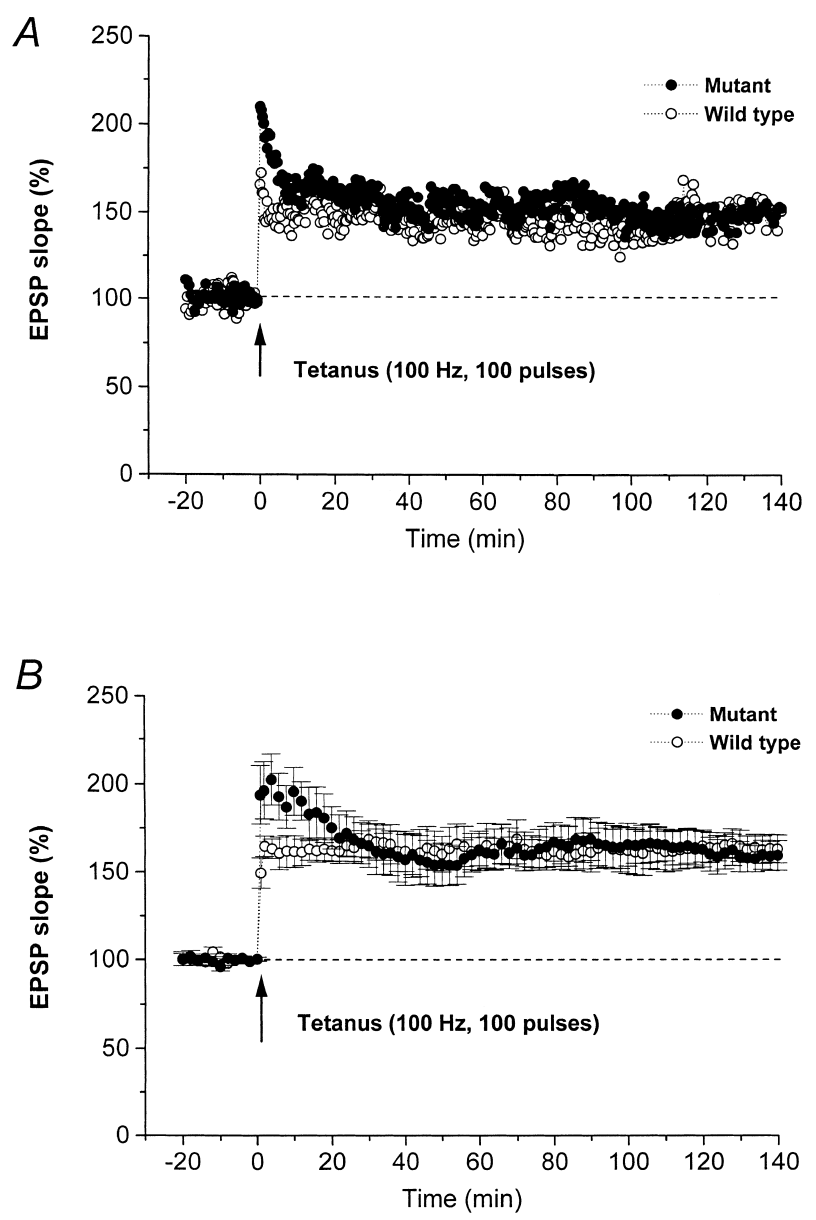

Figure 2 LTP induced by a standard tetanus in slices from wildtype and mutant mice. (A) Typical example of the time-course for S-EPSP. A stable LTP was induced by a standard tetanus (100 pulses at $100 \mathrm{~Hz}$ ) in slices from both a wild-type (open circles) and a mutant (closed circles) mouse. (B) Summarized time-course data for LTP induced in wild-type ( $n=5$, open circles) and mutant ( $n=5$, closed circles) mice.

\section{LTD Induced by a Short LFS in Hippocampal CA1 Neurons of Mice Lacking the IP3R1}

At hippocampal CA1 neuron synapses, a short LFS (200 pulses at $1 \mathrm{~Hz}$ ) induced a robust LTD in slices from both mutant and wild-type mice. Figure 4A shows an example of the time-course of LTD in a representative slice from a mutant and a wild-type mouse. The summarized results from five experiments in five mutant and five wild-type mice (Fig. 4B) clearly show that LTD was induced in slices from both genotypes. To statistically evaluate LTDs, we measured the S-EPSP 60 min after LFS in these slices; in mutant mice, this was $91.7 \% \pm 3.5 \%$ of the pre-LFS control level, whereas, in wild-type mice, it was $91.0 \% \pm 1.5 \%$, with no significant difference between the groups. Thus, a short LFS induced a similar degree of LTD in both genotypes.

The LTD induced in both genotypes was dependent on activation of NMDA glutamate receptors $/ \mathrm{Ca}^{2+}$ channels. Fig- ure $4 \mathrm{C}$ shows a representative time-course plot in a slice from a mutant or wild-type mouse, in both of which LTD in the S-EPSP was blocked when a short LFS was applied in the presence of AP5 $(50 \mu \mathrm{M})$. Figure 4D shows the summarized results from five experiments in five mutant and five wildtype mice, in both of which the S-EPSP increased above the pre-LFS control level after a short LFS applied in the presence of $50 \mu \mathrm{M}$ AP5. The S-EPSP measured $60 \mathrm{~min}$ after the LFS was $118.9 \% \pm 4.9 \%$ or $122.1 \% \pm 2.9 \%$ of the pre-LFS control levels for mutant or wild-type mice, respectively, both of which were significantly greater $(P<0.01)$ than the values seen in the absence of AP5. This shows that LTDs induced in hippocampal CA1 neurons of both genotypes require the activation of NMDA receptor/ $\mathrm{Ca}^{2+}$ channels during LFS. Thus, we conclude that in hippocampal CA1 neurons, IP3R1 is not involved in the mechanism of LTD induction, which requires the activation of NMDA receptor/ $\mathrm{Ca}^{2+}$ channels during LFS.

\section{LTP Suppression in Hippocampal CA1 Neurons of Mice Lacking the IP3R1}

In hippocampal CA1 neurons of wild-type mice, the standard LFS (1000 pulses at $1 \mathrm{~Hz}$ ) given $60 \mathrm{~min}$ prior to a standard tetanus suppresses subsequent LTP induction in the S-EPSP (LTP suppression). Figure 5A shows a representative time-course plot of LTP suppression in a wild-type mouse in which the STP fell gradually back to the pretetanic level within 40-50 min, while Figure 5B summarizes the data from six slices from six wild-type mice, showing that the S-EPSP 60 min after the end of LFS was $81.8 \% \pm 4.8 \%$ of the pre-LFS control level, indicating that LTD was induced by the standard LFS. In addition, tetanus delivered $60 \mathrm{~min}$ after LFS produced STP but failed to induce LTP in the S-EPSP; the S-EPSP measured $60 \mathrm{~min}$ after tetanus being $100.2 \% \pm 15.6 \%$ of the pre-LFS control level. As the percentage change in S-EPSP after tetanus is included in the responses 60 min after LFS delivery, the magnitude of the LTP will be underestimated; when this was taken into consideration, the true magnitude of the LTP was found to be $119.4 \% \pm 13.5 \%$ of the pretetanic level, significantly lower $(P<0.05)$ than the control LTP induced in naive slices from wild-type mice (Fig. 2B).

In mutant mice, LTD was induced and LTP suppression was inhibited in all slices tested. Figure 5A shows a representative time-course plot in which, following delivery of a standard LFS, a standard tetanus evoked a marked increase in S-EPSP that was maintained for $>1 \mathrm{~h}$. Figure $5 \mathrm{~B}$ shows the summarized data for six slices from three mutant mice. The S-EPSP measured $60 \mathrm{~min}$ after the end of LFS was $82.0 \% \pm 4.5 \%$ of control levels, almost equal to the LTD induced in wild-type mice. However, tetanus given $60 \mathrm{~min}$ after LFS resulted in a robust LTP, the S-EPSP measured 60 min after tetanic stimulation being $143.8 \% \pm 11.0 \%$ of the pre-LFS control level or $174.0 \% \pm 3.5 \%$ of the pretetanic

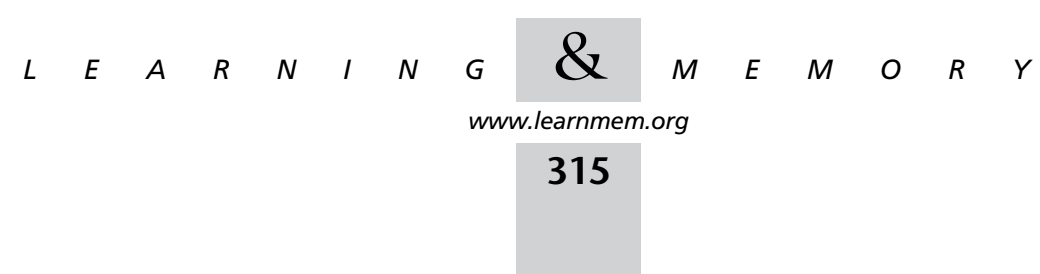



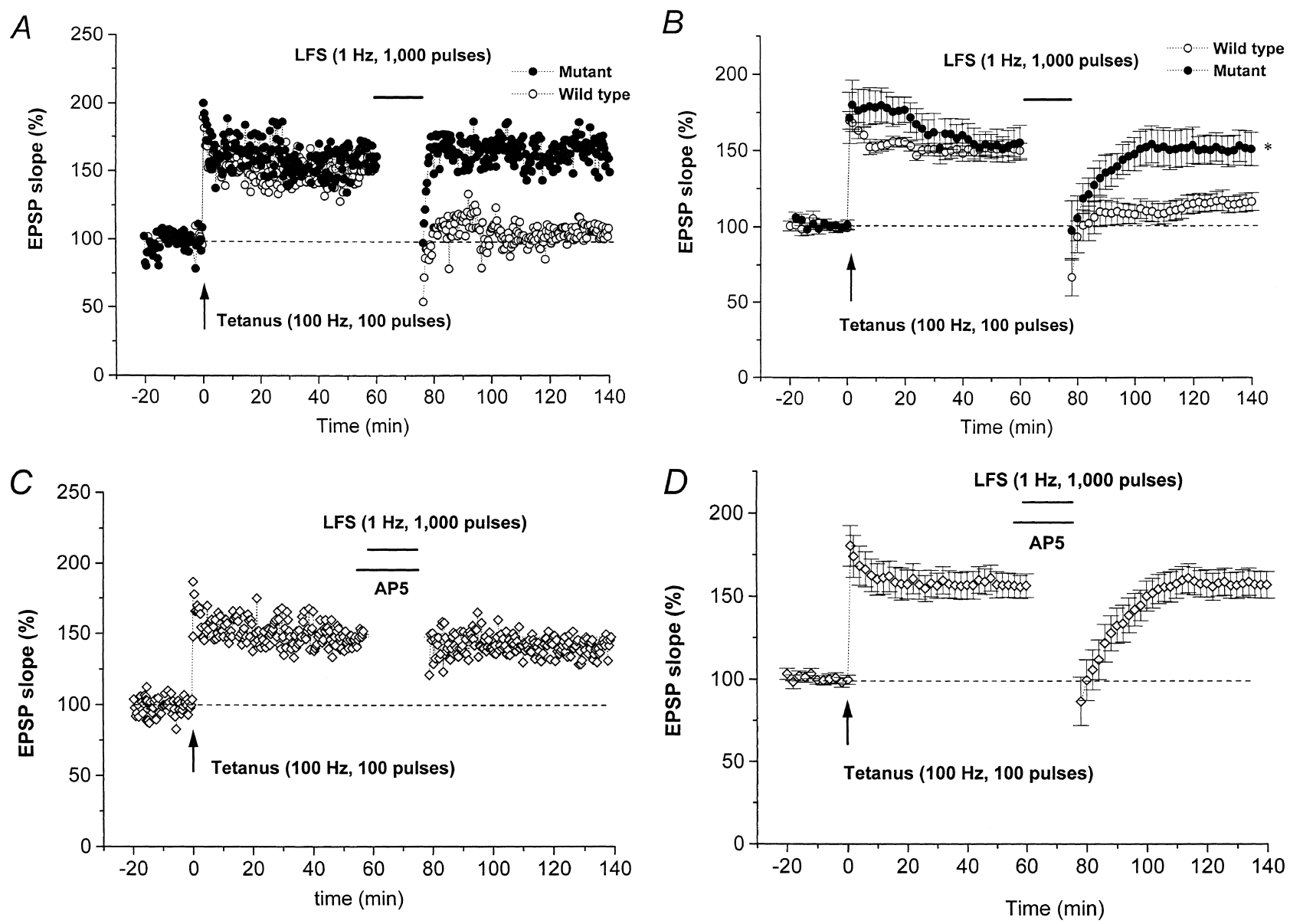

Figure 3 DP in slices from wild-type and mutant mice. (A) Typical example of the time-course for S-EPSP in a slice from a wild-type (open circles) and a mutant (closed circles) mouse. A train of low-frequency stimuli (LFS, horizontal bar) given 60 min after the standard tetanus (arrow) reduced LTP close to the control level in a wild-type mouse but not in a mutant mouse. (B) Summarized time-course data for DP in S-EPSP for wild-type $\left(n=6\right.$, open circles) and mutant $\left(n=7\right.$, closed circles) mice. ${ }^{*}$, significant $(P<0.05)$ difference in the S-EPSP at 60 min after LFS between slices from wild-type and mutant mice. (C) Typical example of time-course of S-EPSP showing that the standard LFS applied to a slice from a wild-type mouse in the presence of AP5 $(50 \mu \mathrm{M}$, horizontal bar) failed to induce DP (open diamonds). (D) Summarized time-course data for S-EPSP in wild-type mice ( $n=4$, open diamonds) when the LFS (upper horizontal bar) was delivered in the presence of $50 \mu \mathrm{M}$ AP5 (lower horizontal bar). DP was blocked by AP5 applied during the standard LFS.

levels, respectively; the former value is significantly greater $(P<0.05)$ than that for the control suppression of LTP in wild-type mice (Fig. 5B), while the latter does not differ significantly from that for the control LTP in mutant mice (Fig. 2B). These results indicate that at CA1 synapses of mice lacking the IP3R1, LTP suppression is blocked, while LTD induction is not affected.

\section{DISCUSSION}

As DP was markedly attenuated (Fig. 3) and LTD unaffected (Figs. 4,5) in hippocampal CA1 neurons of mice lacking the IP3R1, we conclude that the IP3R1 is involved in DP but is not essential for LTD. The facilitation of LTP induction and the absence of DP and LTP suppression seen in hippocampal CA1 neurons in the mutant mice (Figs. 1,4,5) indicate that synaptic transmission is readily potentiated by input activity and maintained because of blockade of DP at CA1 synapses lacking the IP3R1. Thus, we conclude that the IP3R1 plays an important role in blocking synaptic potentiation in hippocampal CA1 neurons.

It is widely believed that an increase in the postsynaptic $\mathrm{Ca}^{2+}$ concentration ([Ca $\left.{ }^{2+}\right] \mathrm{i}$ ) through NMDA receptor/ $\mathrm{Ca}^{2+}$ channels during or after tetanus is a necessary step in the induction of homosynaptic LTP in hippocampal CA1 neurons (Bliss and Collingridge 1993). Similarly, in hippocampal CA1 neurons, the homosynaptic LTD induced by LFS appears to require activation of NMDA receptors and an increase in the postsynaptic $\left[\mathrm{Ca}^{2+}\right] \mathrm{i}$, which triggers activation of $\mathrm{Ca}^{2+}$-dependent second messenger systems (Dudeck and Bear 1992), followed by calcium-independent signaling steps (Mulkey et al. 1994; Bear and Abraham 1996). Thus, in hippocampal CA1 neurons, LTP and LTD share a common

$$
\begin{array}{ccccccccccccc}
L & E & A & R & N & I & N & G \quad \\
\begin{array}{c}
\text { www.learnmem.org } \\
316
\end{array} & \mathbb{Z} \quad M & E & M & O & R & Y
\end{array}
$$



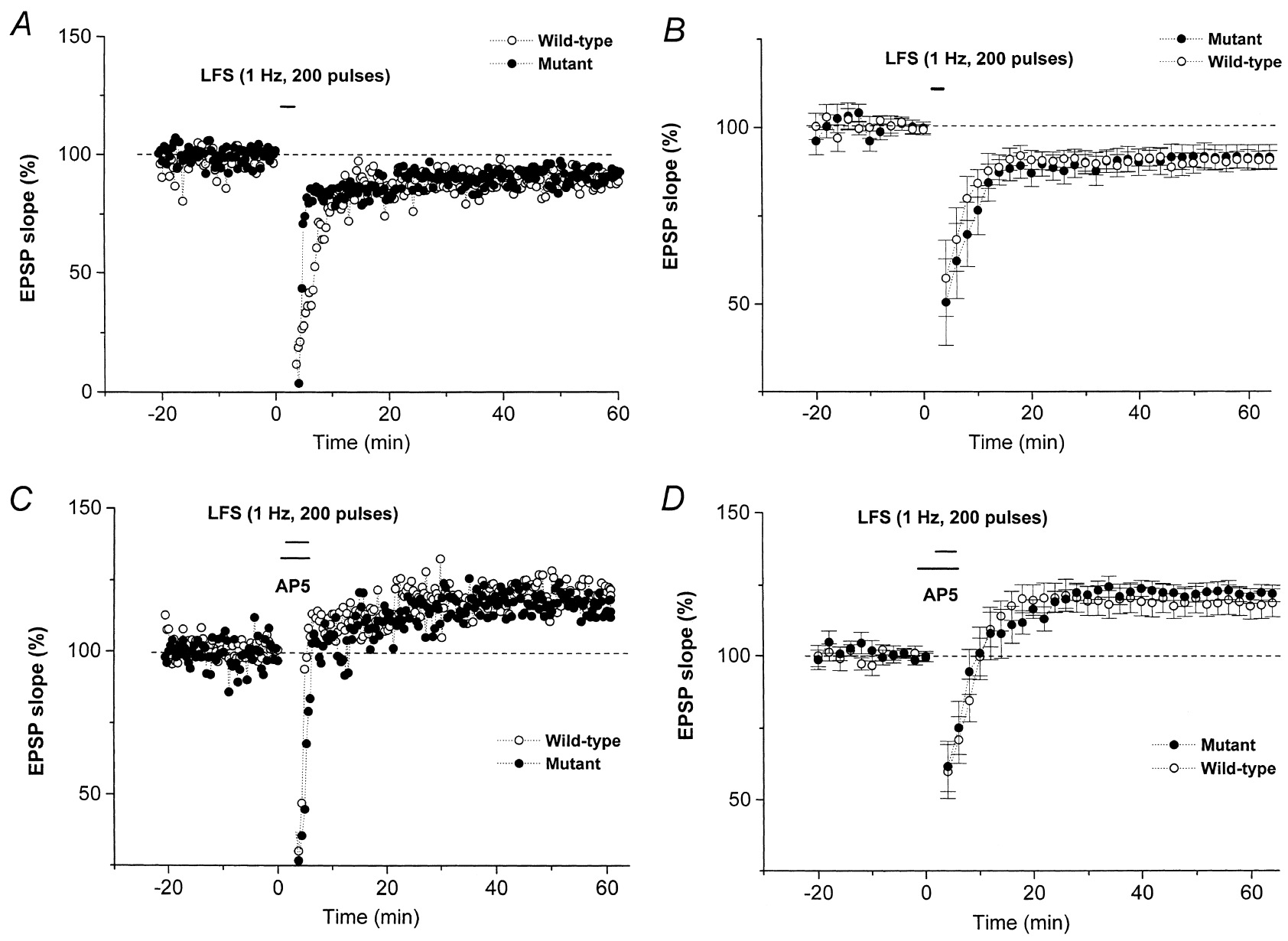

Figure 4 LTD induced by a short LFS in slices from wild-type and mutant mice. (A) Typical example of the time-course of S-EPSP. LTD was induced by a short LFS train (200 pulses at $1 \mathrm{~Hz}$ ) in slices from both a wild-type (open circles) and a mutant (closed circles) mouse. (B) Summarized time-course data for LTD induced in wild-type ( $n=5$, open circles) and mutant ( $n=5$, closed circles) mice. (C) Typical example of the time-course of S-EPSP showing that a short LFS (upper horizontal bar) given in the presence of $50 \mu$ M AP5 (lower horizontal bar) failed to induce LTD in a slice from a wild-type (open circles) and a mutant (closed circles) mouse. (D) Summarized time-course data for S-EPSP from wild-type ( $n=5$, open circles) and mutant ( $n=5$, closed circles) mice when the LFS (upper horizontal bar) was applied in the presence of AP5 (lower horizontal bar).

triggering step, namely an increase in the $\left[\mathrm{Ca}^{2+}\right] \mathrm{i}$ as a result of $\mathrm{Ca}^{2+}$ influx from the extracellular space (Lisman 1994).

However, two distinct calcium-releasing sites on the surface of the internal stores of the endoplasmic reticulum have been identified, these being the ryanodine receptor (calcium-induced calcium release; CICR) and the IP3 receptor (IP3-induced calcium release; IICR). The type 3 ryanodine receptor (RyR3) is enriched in hippocampal CA1 neurons (Furuichi et al. 1994). RyR3-deficient mice produced by gene targeting exhibit facilitated LTP induced by a short tetanus (10 pulses at $100 \mathrm{~Hz})$ at hippocampal CA1 synapses, suggesting that CICR as a result of $\mathrm{Ca}^{2+}$ influx during or after tetanus contributes to the blockade of LTP induction in hippocampal CA1 neurons (Futatsugi et al. 1999).

This study demonstrated that mice lacking the IP3R1 showed facilitated LTP induced by a short tetanus (10 pulses at $100 \mathrm{~Hz}$ ) at hippocampal CA1 synapses and that this was dependent on activation of NMDA glutamate receptors $/ \mathrm{Ca}^{2+}$ channels. This suggests that in hippocampal CA1 neurons, LTP induction by a short tetanus is actively blocked by postsynaptic IICR but is triggered by $\mathrm{Ca}^{2+}$ influx through NMDA receptor/Ca ${ }^{2+}$ channels. It is therefore possible that in these cells, increases in the $\left[\mathrm{Ca}^{2+}\right] \mathrm{i}$, mediated either by efflux from internal stores via the IP3R1 or RyR3 or by $\mathrm{Ca}^{2+}$ influx through NMDA receptors, play opposing roles in LTP induction.

In contrast, in both genotypes, a standard tetanus (100 pulses at $100 \mathrm{~Hz}$ ) induced a similar degree of LTP that was maintained for at least $140 \mathrm{~min}$ (Fig. 2). This may indicate that postsynaptic IICRs cannot block LTP induction by a standard tetanus. LTP induction in hippocampal CA1 neurons requires sufficient depolarization of the postsynaptic

$$
\begin{array}{ccccccccccccc}
L & E & A & R & N & I & N & G \quad \\
\begin{array}{c}
\text { www.learnmem.org } \\
317
\end{array} & \mathbb{3} \quad M & E & M & O & R & Y
\end{array}
$$



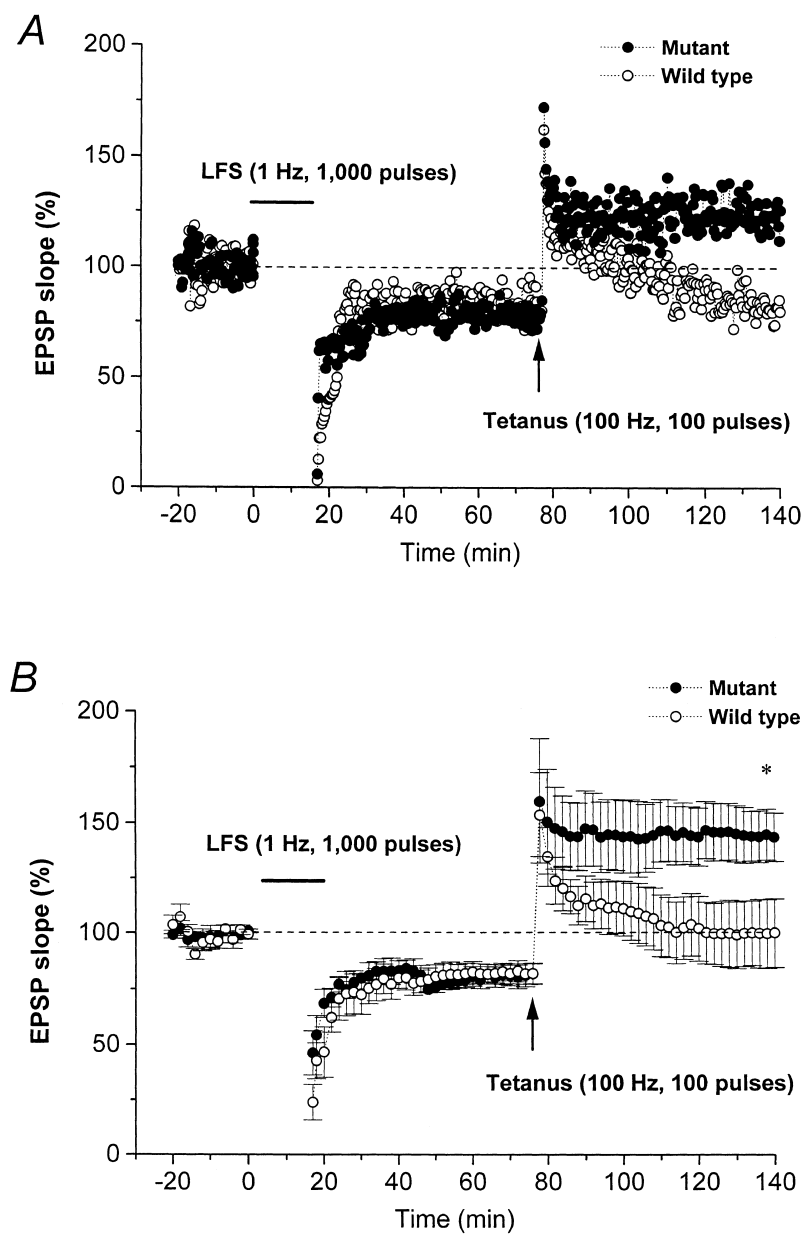

Figure 5 LTP suppression by low-frequency stimulation (LFS, horizontal bar) delivered $60 \mathrm{~min}$ before a standard tetanus. $(A)$ Typical time-course of LTP suppression in a slice from a wild-type (open circles) and a mutant (closed circles) mouse. In the wild-type mouse, LFS induced long-term depression (LTD) in S-EPSP but suppressed subsequent LTP induction. In the mutant mouse, LFS given before tetanus-induced LTD failed to suppress LTP induction. $(B)$ Summarized time-course data for LTD and LTP suppression in slices from wild-type ( $n=6$, open circles) and mutant $(n=6$, closed circles) mice. ${ }^{*}$, significant $(P<0.05)$ difference in the $\mathrm{S}$ EPSP at $60 \mathrm{~min}$ after tetanus between slices from wild-type and mutant mice.

membrane to activate NMDA receptor/ $\mathrm{Ca}^{2+}$ channels, and this depolarization depends on input activity (Ascher and Nowak 1988; Collingridge et al. 1988a,b). Furthermore, an increase in $\left[\mathrm{Ca}^{2+}\right]$ i through VGCCs, which also depends on input activity, is thought to contribute to LTP induction (Ito et al. 1995). It is possible that postsynaptic IICRs activated during a standard tetanus cannot antagonize the large $\mathrm{Ca}^{2+}$ influx through NMDA receptor/ $/ \mathrm{Ca}^{2+}$ channels or VGCCs, which is more dominant in LTP formation. Thus, it is assumed that the IP3R1 is involved in the mechanism of LTP by limiting LTP induction.

Group I mGluRs activate PLC, which hydrolyses phos- phatidyl inositol bisphosphate (PIP2) into IP3 and DAG, the former opening IP3 receptor channels and the latter activating PKC. In hippocampal CA1 neurons, however, mGluR-dependent LTD does not involve activation of NMDA receptors and is thought to be mechanistically distinct from NMDA receptor-dependent LTD (Oliet et al. 1997; Palmer et al. 1997; Otani and Connor 1998). That an NMDA receptor antagonist blocked LTD in mice lacking the IP3R1 (Fig. 4C,D) provides evidence that the IP3R1 is not involved in the mechanism of NMDA receptor-dependent LTD in hippocampal CA1 neurons.

Both LTD and DP are synapse-specific effects and are induced optimally by $1-\mathrm{Hz}$ LFS, suggesting that DP shares some features with LTD. In hippocampal CA1 neurons, activation of NMDA receptor/ $\mathrm{Ca}^{2+}$ channels is involved in both LTD and DP, since D, L-AP5 $(50 \mu \mathrm{M})$, applied during 1 Hz LFS (200 or 1000 pulses), blocked the induction of both DP and LTD (Figs. 3D, 4D), suggesting that DP is a form of LTD. In contrast, in mice lacking the IP3R1, the effects of 1 -Hz LFS on DP were quite different from those in normal mice, LFS (1000 pulses at $1 \mathrm{~Hz}$ ) inducing LTD in naive slices without reversal of the established LTP (Figs. 3B, 5B). This indicates that LTD and DP in hippocampal CA1 neurons are mechanistically distinct forms of synaptic plasticity and, as the only procedural difference between DP and LTD induction was the absence or presence of tetanic stimulation, that the IP3R1 is involved in DP but not in LTD.

LTP and LTD may be mediated by modulation of $\alpha$-amino-3-hydroxy-5-methyl-4-isoxazole propionic acid (AMPA) receptor phosphorylation (Lee et al. 1998; Barria et al. 1997). Recently, Lee et al. (2000) showed that LTD and DP dephosphorylate two phosphorylation sites on the AMPA receptor GluR1 subunit, these being the major cyclic AMP dependent protein kinase A site and the calcium/ calmodulin-dependent protein kinase II (CaMKII) site. Considering the results of this study, it is possible that the phospholipid-IP3R1-IICR-CaMKII-dependent second-messenger system (Lisman 1994) is involved in DP.

Coactivation of NMDA receptors and mGluRs is considered necessary for tetanus-induced LTP in hippocampal CA1 neurons (Bortolotto and Collingridge 1993; Sergueeva et al. 1993; Brown et al. 1994). Bortolotto et al. (1994) reported that delivery of $2-\mathrm{Hz}$ LFS to the CA1 inputs of naive rat hippocampal slices deconditions the mGluRs-activated molecular switch and suppresses LTP induction by subsequent tetanic stimulation (100 pulses at $100 \mathrm{~Hz}$ ). However, NMDA receptor/ $\mathrm{Ca}^{2+}$ channels may be involved in the mechanism of LTP suppression, as D, L-AP5 (50 $\mu \mathrm{M})$, applied during LFS, successfully blocks LTP suppression (Fujii 1996). The failure of LTP suppression in slices from mice lacking the IP3R1 (Fig. 5) suggests that LTP is readily induced at synapses at which the mGluR-activated molecular switch is inoperative because of the absence of the IP3R1, and that activation of IP3R1 during or after LFS, together

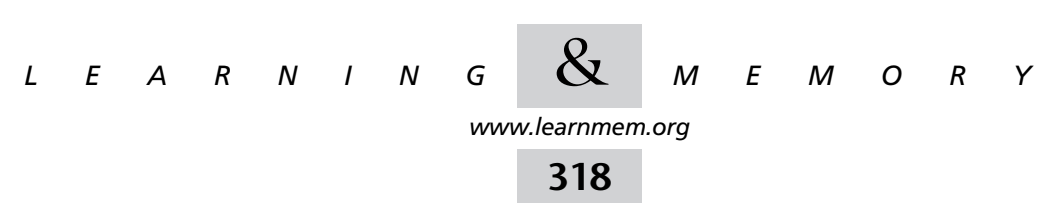


with activation of NMDA receptor/ $\mathrm{Ca}^{2+}$ channels, triggers signaling steps to block the subsequent LTP induction.

LTP suppression has an effective time window during which the following tetanus fails to produce LTP; that is, LTP induction is suppressed by LFS delivered $60 \mathrm{~min}$, but not 20 or $100 \mathrm{~min}$, before tetanus (Fujii et al. 1996). This explains the failure of LTP suppression by 1-Hz LFS (900 pulses) at hippocampal CA1 synapses studied in vivo (Heynen et al. 1996) or in vitro (Lee et al. 2000). In these studies, tetanus (100 pulses at $100 \mathrm{~Hz}$ ) was delivered about $30 \mathrm{~min}$ after the end of LFS (Heynen et al. 1996), or $\theta$-burst stimulation (10 bursts of 5 pulses at $100 \mathrm{~Hz}$ with interburst intervals of $200 \mathrm{msec}$ ) was delivered $\sim 20$ or $80 \mathrm{~min}$ after the end of LFS (Lee et al. 2000). As the second-messenger systems that are triggered by a large influx into the cell through NMDA receptor $/ \mathrm{Ca}^{2+}$ channels are activated within, at most, a few seconds or minutes (Ben-Ari et al. 1992; Lisman 1994), a further step after the early second-messenger systems might be involved in LTP suppression. The molecular mechanism involved in LTP suppression is of considerable interest, but it is too early to draw any detailed conclusions.

In summary, our results suggest that, in hippocampal CA1 neurons, the IP3R1 is involved in LTP, DP, and LTP suppression but is not essential for LTD. The facilitation of LTP induction and attenuation of DP and LTP suppression seen in mice lacking the IP3R1 indicates that this receptor plays an important role in blocking synaptic potentiation in hippocampal CA1 neurons.

\section{Materials and Methods}

The animals used were maintained and handled following the guidelines of the Animal Care and Use Committee of the Yamagata University School of Medicine. The techniques were almost identical to those described previously (Fujii et al. 1996). The procedures for IP3 gene targeting and the production of homozygous mutant (-/-) mice on a C57BL/6J background were as described previously (Matsumoto et al. 1996). A neomycin-resistant J1 embryonic stem cell clone was identified as a homologous recombinant and used to generate heterozygous mutant $(+/-)$ mice that grew normally and showed no obvious defects. When the heterozygotes were mated, most of the homozygous mutants died in uteri, while others died postnatally; at postnatal day 10 , wild-type $(+/+)$, heterozygous (+/-), and homozygous (-/-) mutant mice were found at the respective frequencies of $33.5 \%, 61.0 \%$, and $5.5 \%$ $(1.10: 2.00: 0.18 ; n=271)$. The genotypes were identified using the polymerase chain reaction and Southern blot analysis (Matsumoto et al. 1996).

Recordings were performed on hippocampal slices prepared from age-matched 18- to 22-d-old homozygous mutant IP3R1 knockout $\mathrm{C} 57 \mathrm{BL} / 6 \mathrm{~J}$ mice and their wild-type littermates, and the results were compared. Hippocampi were rapidly dissected and transverse slices $(500 \mu \mathrm{m}$ thick) preincubated for at least $1 \mathrm{~h}$ in standard medium, consisting of $124 \mathrm{mM} \mathrm{NaCl}, 5.0 \mathrm{mM} \mathrm{KCl}, 1.25 \mathrm{mM}$ $\mathrm{NaH}_{2} \mathrm{PO}_{4}, 2.0 \mathrm{mM} \mathrm{MgSO}_{4}, 2.5 \mathrm{mM} \mathrm{CaCl}, 22.0 \mathrm{mM} \mathrm{NaHCO}_{3}$, and $10.0 \mathrm{mM}$ glucose, maintained at $30^{\circ}-32^{\circ} \mathrm{C}$, and constantly bubbled with a mixture of $5 \% \mathrm{CO}_{2} / 95 \% \mathrm{O}_{2}$. To stimulate the input pathways to the CA1 neurons, a bipolar stimulating electrode was placed in the stratum radiatum of the CA1 region, close to the CA2 region, and a glass recording electrode filled with standard medium (impedance 5-15 $\mathrm{M} \Omega$ ) was placed in the stratum radiatum of the CA1 region $0.6-1.5 \mathrm{~mm}$ from the stimulating electrode. The strength and duration of the stimulus pulse were adjusted to elicit a field EPSP with an initial slope $40 \%-60 \%$ of maximum and were then fixed at this level for each experiment.

After checking the stability of the responses to a test stimulus given at 20-sec intervals, either a short (10 pulses at $100 \mathrm{~Hz})$ or a standard (100 pulses at $100 \mathrm{~Hz})$ tetanus was delivered to elicit LTP. In LTD experiments, a short (200 pulses at $1 \mathrm{~Hz})$ or a standard (1000 pulses at $1 \mathrm{~Hz})$ LFS was delivered. For DP, delivery of a standard LFS (1000 pulses at $1 \mathrm{~Hz})$ was initiated 60 min after the tetanus. In LTP suppression experiments, the standard LFS (1000 pulses at $1 \mathrm{~Hz}$ ) was delivered $60 \mathrm{~min}$ before the standard tetanus used to elicit LTP. After delivery of the tetanus or LFS, the test stimulus was repeated every $20 \mathrm{sec}$ and responses recorded for a minimum of $60 \mathrm{~min}$. To evaluate changes in the response, the mean value of the slope of the field EPSP (S-EPSP) in the 10-min period before the delivery of the tetanus or LFS to naive slices was defined as the control $(100 \%)$ level, and responses after tetanus or LFS expressed as a percentage (mean \pm SEM) of this. In addition, a short tetanus or a short LFS was given in the presence of the N-methylD-aspartate (NMDA) glutamate receptor antagonist, D, L-2 amino5-phosphonovalerate (AP5, $10 \mu \mathrm{M}$ or $50 \mu \mathrm{M}$, Research Biochemical Incorporated), and changes in the S-EPSP measured $60 \mathrm{~min}$ after the short tetanus or short LFS. The test reagent was applied 3-5 min before and during the tetanus or LFS, then was replaced by the standard solution just after the end of the tetanus or LFS.

All values are given as the mean \pm SEM (\%). The results were analyzed for statistical significance $(P<0.05$ or $P<0.01)$ using the two-tailed Student's test.

The publication costs of this article were defrayed in part by payment of page charges. This article must therefore be hereby marked "advertisement" in accordance with 18 USC section 1734 solely to indicate this fact.

\section{REFERENCES}

Abeliovich, A., Chen, C., Goda, Y., Silva, A.J., Stevens, C.F., and Tonegawa, S. 1993. Modified hippocampal long-term potentiation in PKC $\gamma$-mutant mice. Cell 75: 1253-1262.

Ascher, P. and Nowak, L. 1988. The role of divalent cations in the $\mathrm{N}$-methyl-D-aspartate responses of mouse central neurons in culture. $J$. Physiol. 399: 247-266.

Barria, A., Muller, D., Derkach, V., Griffith, L.C., and Soderling, T.R. 1997 Regulatory phosphorylation of AMPA-type glutamate receptors by CaM-KII during long-term potentiation. Science 276: 2042-2045.

Bashir, Z.I. and Collingridge, G.L. 1994. An investigation of depotentiation of long-term potentiation in the CA1 region of the hippocampus. Exp. Brain Res. 100: 437-443.

Bashir, Z.I., Bortolotto, Z.A., Davies, C.H., Berretta, N., Irving, A.J., Seal, A.J., Henley, J.M., Jane, D.E., Watkins, J.C., and Collingridge, G.L. 1993. Induction of LTP in the hippocampus needs synaptic activation of glutamate metabotropic receptors. Nature 363: 347-350.

Bear, M.F. and Abraham, W.C. 1996. Long-term synaptic depression. Annu. Rev. Neurosci. 19: 437-462.

Ben-Ari, Y., Anikstzen, L., and Bregestovski, P. 1992. Protein kinase C modulation of NMDA currents: An important link for LTP induction. Trends Neurosci. 5: 333-339.

Berridge, M.J. 1993. Inositol trisphosphate and calcium signalling. Nature 361: $315-325$

Bliss, T.V.P. and Collingridge, G.L. 1993. A synaptic model of memory: Long-term potentiation in the hippocampus. Nature 361: 31-39.

Bliss, T.V.P. and Gardner-Medwin, A.R. 1973. Long-lasting potentiation of

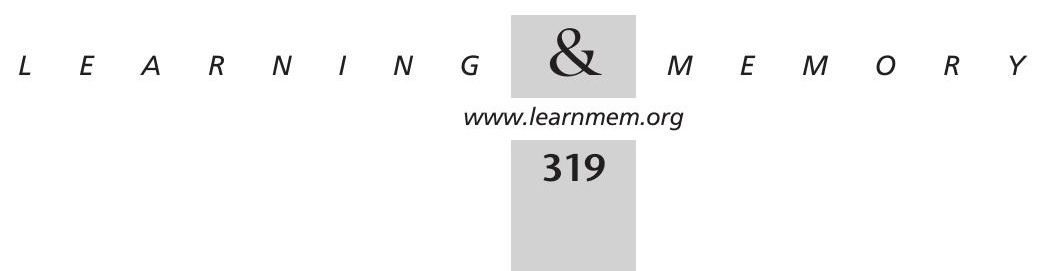


synaptic transmission in the dentate area of the unanesthetized rabbit following stimulation of the perforant path. J. Physiol. 232: 357-374.

Bliss, T.V.P. and Lømo, T. 1973. Long-lasting potentiation of synaptic transmission in the dentate area of the anesthetized rabbit following stimulation of the perforant path. J. Physiol. 232: 331-356.

Bortolotto, Z.A. and Collingridge, G.L. 1993. Characterisation of LTP by the activation of glutamate metabotropic receptors in area CA1 of the hippocampus. Neuropharmacology 32: 1-9.

Bortolotto, Z.A., Bashir, Z.I., Davies, C.H. and Collingridge, G.L. 1994. A molecular switch activated by metabotropic glutamate receptors regulates induction of long-term potentiation. Nature 368: 740-743.

Brown, R.E., Rabe, H., and Reymann, K.G. 1994. (RS)- $\alpha$-Methyl-4-carboxyphenylglycine (MCPG) does not block $\theta$ burst-induced long-term potentiation in area CA1 of rat hippocampal slices. Neurosci. Lett. 170: 17-21.

Collingridge, G.L., Herron, C.E., and Lester, R.A. 1988a. Synaptic activation of N-methyl-D-aspartate responses in the Schaffer collateral-commissural pathway of rat hippocampus. J. Physiol. 399: 283-300

- 1988b. Frequency-dependent N-methyl-D-aspartate receptor mediated synaptic transmission in rat hippocampus. J. Physiol. 399: 283-300.

Dudeck, S.M. and Bear, M.F. 1992 Homosynaptic long-term depression in area CA1 of hippocampus and effects of N-methyl-D-aspartate receptor blockade. Proc. Natl. Acad. Sci. 89: 4363-4367.

Fujii, S., Saito, K., Ito, K.-I., Miyakawa, H., and Kato, H. 1991. Reversal of long-term potentiation (depotentiation) induced by tetanus stimulation of the input to CA1 neurons of guinea pig hippocampal slices. Brain Res. 555: 112-122.

Fujii, S., Kuroda, Y., Miura, M., Furuse. H., Sasaki, H., Kaneko, K., Ito, K.-I. and Kato, H. 1996. The long-term suppressive effect of prior activation of synaptic inputs by low-frequency stimulation on induction of long-term potentiation in CA1 neurons of guinea-pig hippocampal slices. Exp. Brain Res. 111: 305-312.

Fujii, S., Kuroda, Y., Ito, K.-I., Yoshioka, M., Kaneko, K., Yamazaki, Y., Sasaki, H., and Kato, H. 2000. Endogenous adenosine regulates the effects of low-frequency stimulation on the induction of long-term potentiation in CA1 neurons of guinea pig hippocampal slices. Neurosci. Lett. 279: 121-124.

Furuichi, T., Simon-Chazottes, D., Fujino, I., Yamada, N., Hasegawa, M., Miyawaki, A., Yoshikawa, S., Guenet, J.-L., and Mikoshiba, K. 1993. Widespread expression of inositol 1,4,5-trisphosphate receptor type 1 gene in the mouse central nervous system. Recept. Channels 1: 11-24

Furuichi, T., Furutama, D., Hakamata, Y., Nakai, J., Takeshima, H., and Mikoshiba, K. 1994. Multiple types of ryanodine receptor/Ca ${ }^{2+}$ release channels are differentially expressed in rabbit brain. J. Neurosci. 14: $4794-4805$

Futatsugi, A., Kato, K., Ogura, H., Li, S.-T., Nagata, E., Kuwajima, G., Tanaka, K., Itohara, G., and Mikoshiba, K. 1999. Facilitation of NMDA-independent LTP and spatial learning in mutant mice lacking ryanodine receptor type 3. Neuron 24: 701-713.

Heynen, A.J., Abraham, W.C., and Bear, M.F. 1996. Bidirectional modification of CA1 synapses in the adult hippocampus in vivo. Nature 381: 163-166.

Inoue, T., Kato, K., Kohda, K., and Mikoshiba, K. 1998. Type 1 Inositol 1,4,5-trisphosphate receptor is required for induction of long-term depression in cerebellar Purkinje neurons. J. Neurosci. 18: 5366-5373.
Ito, K.-I., Miura, M., Furuse, H., Chen, Z., Kato, H. Yasutomi, D., Inoue, T., Kimura, T., Sakakibara, S., and Miyawaki, H. 1995. Voltage-gated $\mathrm{Ca}^{2+}$ channel blockers, $\omega$-Aga IV and $\mathrm{Ni}^{2+}$, suppress the induction of $\theta$-burst induced long-term potentiation in guinea pig hippocampal CA1 neurons. Neurosci. Lett. 183: 112-115.

Kato, K., Uruno, K., Saito, K., and Kato, H. 1991. Both arachidonic acid and 1-oleoyl-2-acetyl glycerol in low magnesium solution induce long-term potentiation in hippocampal CA1 neurons in vitro. Brain Res. 563: 94-100.

Lee, H.-K., Kameyama, K., Huganir, R.L., and Bear, M.F. 1998. NMDA induces long-term synaptic depression and dephosphorylation of the GluR1 subunit of AMPA receptors in hippocampus. Neuron 21: 1151-1162.

Lee, H.-K., Barbaroside, M., Kameyama, K., Bear, M.F., and Huganir, R.L. 2000. Regulation of distinct AMPA receptor phosphorylation sites during bidirectional synaptic plasticity. Nature 405: 955-959.

Linden, D.J. 1994. Long-term synaptic depression in the mammalian brain Neuron 12: 452-457.

Lisman, J. 1994. The CaM kinase II hypothesis for the storage of synaptic memory. Trends Neurosci. 17: 406-412.

Matsumoto, M., Nakagawa, T., Inoue, T., Nagata, E., Tanaka, K., Takano, H., Minowa, O., Kuno, J., Sakakibara, S., Yamada, M., et al. 1996. Ataxia and epileptic seizures in mice lacking type 1 inositol 1,4,5-trisphosphate receptor. Nature 379: 168-171.

Mikoshiba, K. 1993. Inositol 1,4,5-trisphosphate receptor. Trends Pharmacol. Sci. 14: 86-89.

Mulkey, R.M. and Malenka, R.C. 1992. Mechanism underlying induction of homosynaptic long-term depression. Neuron 9: 967-975.

Mulkey, R.M., Endo, S., Shenolikar, S., and Malenka, R.C. 1994. Involvement of a calcineurin/inhibitor-1 phosphatase cascade in hippocampal long-term depression. Nature 369: 88.

Nakanishi, S. 1992. Molecular diversity of glutamate receptors and implication for brain function. Science 258: 597-603.

O'Dell, T.J. and Kandel, E.R. 1994. Low-frequency stimulation erases LTP through an NMDA receptor-mediated activation of protein phosphatases. Learn. Mem. 1: 129-139.

Oliet, S.H.R., Malenka, R.C., and Nicoll, R.A. 1997. Two distinct forms of long-term depression coexist in CA1 hippocampal pyramidal cells Neuron 18: 969-982.

Otani, S. and Connor, J.A. 1998. Requirement of rapid $\mathrm{Ca}^{2+}$ entry and synaptic activation of metabotropic glutamate receptors for the induction of long-term depression in adult rat hippocampus. J. Physiol. 511: 761-770.

Palmer, M., Irving, A.J., Seabrook, G.R., Jane, D.E., and Collingridge, G.L. 1997. The group I mGlu receptor agonist DHPG induces a novel form of LTD in the CA1 region of the hippocampus. Neuropharmacology 36: $1517-1532$.

Sergueeva, O.A., Fedorov, N.B., and Reymann, K.G. 1993. An antagonist of glutamate metabotropic receptors, (RS)- $\alpha$-methyl-4-carboxyphenylglycine, prevents the LTP-related increase in postsynaptic AMPA sensitivity in hippocampal slices Neuropharmacology 32: 933-935.

Received May 29, 2000; accepted in revised form August 10, 2000.

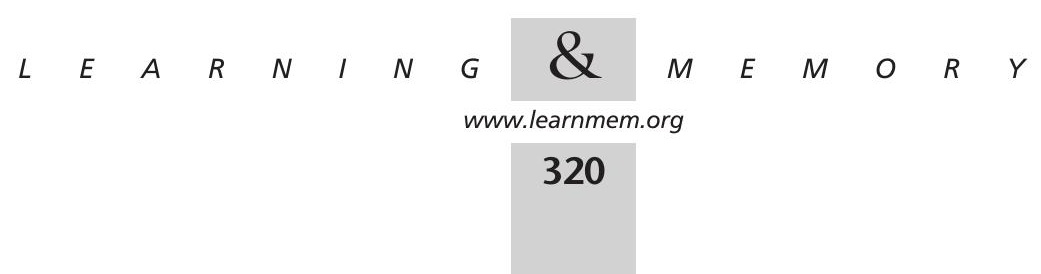




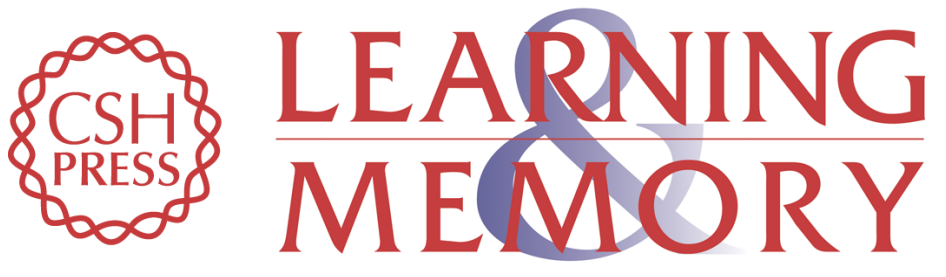

\section{Synaptic Plasticity in Hippocampal CA1 Neurons of Mice Lacking Type 1 Inositol-1,4,5-Trisphosphate Receptors}

Satoshi Fujii, Mineo Matsumoto, Kotaro Igarashi, et al.

Learn. Mem. 2000, 7:

Access the most recent version at doi:10.1101//m.34100

References This article cites 39 articles, 6 of which can be accessed free at: http://learnmem.cshlp.org/content/7/5/312.full.html\#ref-list-1

License

Email Alerting Receive free email alerts when new articles cite this article - sign up in the box at the Service top right corner of the article or click here. 